\title{
Role and Perspective of Sport Science in Health Promotion and Elite Sport
}

\author{
Kijin $\mathrm{Kim}^{1 *}$ \\ ${ }^{1}$ Department of Physical Education, College of Physical Education, Keimyung University
}

\author{
Received: January 24, 2018 \\ Accepted: March 28, 2019 \\ Published online: April 30, 2019 \\ Keywords: \\ Convergence \\ Elite Sports \\ Health Promotion \\ ICT \\ Sport Science
}

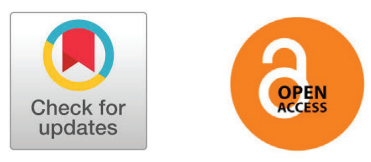

\section{ABSTRACT}

OBJECTIVES The study aimed to investigate the role and perspective of sport science in health promotion and the improvement of elite sport performance.

METHODS The study was performed by the review of previous papers and manuscripts related to sport science development and future.

RESULTS Sport science has emerged as an important part of human science since long ago. In the BC $1800 \mathrm{~s}$, evidence of sports being used as treatment for diseases was the foundation for 'Exercise Medicine', as suggested by ACSM in 2007. Similar to the characteristics of other academics, sport science also shows a periodic wave, alternating between a flow of segmentation and specialization and a flow of convergence and interdependence. The sport science approach not only prevents diseases but also aids in the treatment of diseases. The process of development of evidence-based sports science includes questions on the applicability on the actual setting and collecting evidences of its answer. Sport science must be recognized as an important academic field that provides clear answers to the questions posed by the public, athletes, and coaches. Convergence with diverse modern sciences and evolution is suggested. Convergence of culture industry and increased participation in sports have brought positive effects, including healthy lifestyles, ICT innovation, IT software utilization, sociability among the elderly, development of global sport networks, strengthened tourism industry, and development of sensory virtual reality.

CONCLUSIONS Relative to other academic fields, sport science requires more reality and productivity. Active attempts to investigate in both laboratories and fields, analysis of actual settings, and experience-based interpretation are crucial to truly improve performance and further develop sport science. Sport science in the future will require association and harmony with more diverse academic fields, as well as utilization of modern technology and communication among diversified information technologies. An active association between sport science and sport culture is emphasized.

(c) The Asian Society of Kinesiology and the Korean Academy of Kinesiology

\section{What is sport science?}

\section{Origin of sport science}

Sport science has emerged as an important part of human science since long ago. Physical education and sports activities can be traced back to ancient times of human history. Sport science encompasses research on exercise, sports activity,

*Correspondence: Kijin Kim, Department of Physical Education, College of Physical Education, Keimyung University, 1095 Dalgubeuldero, Dalseo-gu, Daegu, Korea; Tel: +82-053-580-5256; Fax: +82-053-580-5314; E-mail: kjk744@kmu.ac.kr sports humanities, and social sciences. Furthermore, sport science includes natural science, which also belongs to the field of science [1]. Sports activities can be traced back to physical activities in BC times and in English sports and ancient Chinese history. In the BC 1800s, evidence of sports being used as treatment for diseases was the foundation for 'Exercise Medicine' [2], as suggested by ACSM in 2007.

The process of performing sports and physical activities includes civilization and competition. As sports focused on

This is an open-access article distributed under the terms of the Creative Commons Attribution License (http://creativecommons.org/licenses/by-nc/4.0/), which permits unrestricted use, distribution, and reproduction in any medium, provided the original work is properly cited. 


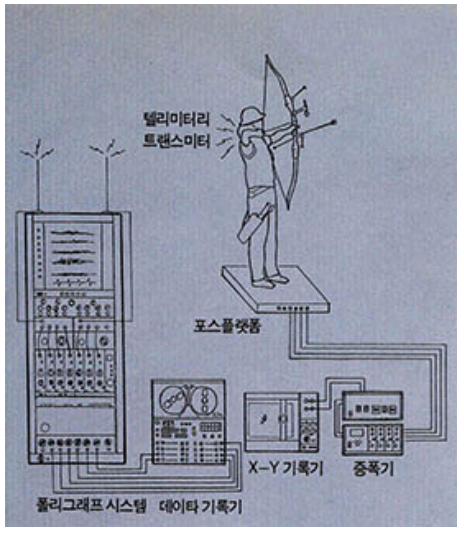

Figure 1. Diagram of analysis of shooting point of Korean national archery team in 1988 (from KISS)

health improvements during entertainment, a more systematic and scientific approach has been attempted. Furthermore, environmental changes have significantly affected changes to the human physical functions. To effectively overcome environmental stimuli, many attempts have been made to approach sports with knowledge and theory based on homeostasis. Sport science trials originated for personal health and injury prevention. Major attempts were first made in the Tokyo Olympics in 1964, where maximization of performance was attempted. In the Mexico Olympics in 1968, medical approaches regarding the high-altitude environment further aided in the advancement of sport science. Olympic sports have also led to scientific advancements in the area, which is best illustrated by the inauguration of the Japanese high-speed rail Shinkansen during the Tokyo Olympics.

\section{What changes has it brought and what role has it played?}

Sports science requires practical applicability of the actual setting, high-quality research, and analysis at the sports setting, use of the actual site, and interpretation based on experience. Sport science in Korea mainly originated in the 1960s. Sport science and its advances of both quantitative and qualitative perspectives played an important role to make Korea a strong sports nation. In terms of performance enhancement, exponential improvements were observed after the Seoul Olympics in 1988 and Korea has obtained outstanding results at international sports events such as the 2016 Rio Summer and 2018 Pyeongchang Winter Olympics. The role of sport science is expanding to public health improvement, academics,

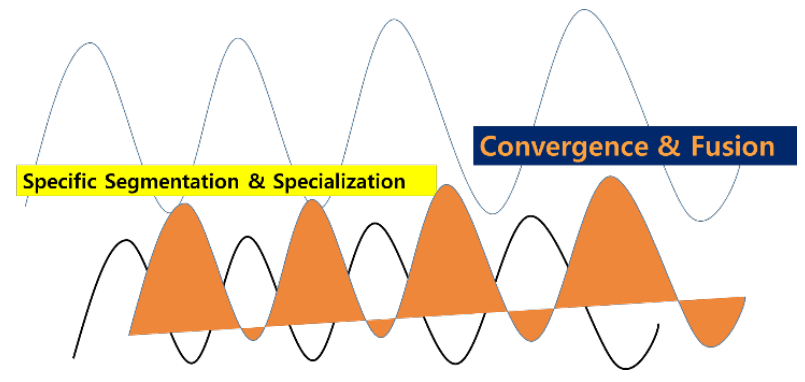

Figure 2. Periodic wave of academic development in sport science

and the sport industry. During this process, researchers in the Korean Alliance for Health, Physical Education, Recreation and Dane, and Korea Institute of Sport Science (KISS) played a huge role.

Sport science encompasses diverse subcategories and has continuously interacted with related academics. With respect to academic development, sport science exhibits two major characteristics in its flow, including periodic wave and a search for new ideas. Similar to the characteristics of other academics, sport science also shows a periodic wave, alternating between a flow of segmentation and specialization and a flow of convergence and interdependence (Fig. 2). Currently, the major flow is convergence and compounding of different subcategories. Furthermore, sport science requires convergence not only between segmented academic fields, but also with other advanced academic fields to acquire new knowledge and theories [3].

Sport science has played important roles in developing scientific training facilities and stadiums, new training methods, and sports equipment. New equipment, such as sports shoes and uniforms that use cutting edge technology, changes in soccer balls and pole vaults (Fig. 3), introduction of the clap skate [4], structure of cycles, materials of golf clubs and balls, arrow and bow compositions of archery, new materials for baseball bats, protective gear for players, and high jump's Fosbury style, have all been developed because of advancement of sport science [3]. Development of the measurement and analysis devices, as well as sports facilities, are crucial to improve sports performance. Although new 


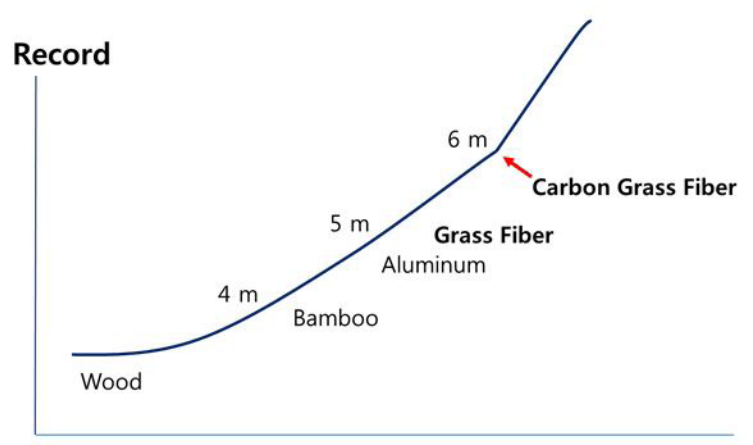

Figure 3. Changes of pole vault's record with pole materials development

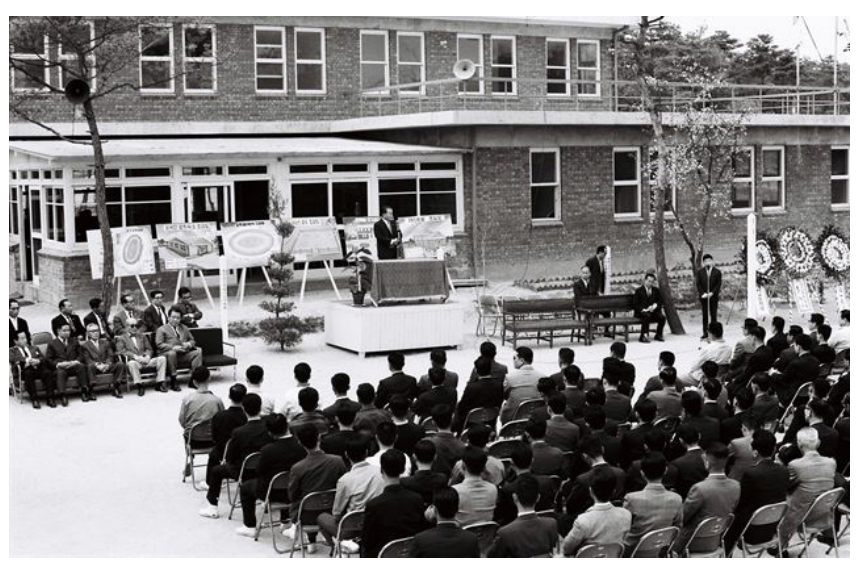

Figure 4. Opening ceremony of Taereung National Training Center in1966 (from KSOC)

sports facilities are now available in Jincheon, the Taereung National Training Center constructed in 1966 played an important role in obtaining the first gold medal in the Montreal Olympics in 1976 (Fig. 4). The indoor rink at the Taereung international skate training center built in January 2000 was a critical factor in obtaining the first gold medal in speed skating in the Vancouver Winter Olympics 10 years later. Hence, we conclude that scientific sport facilities are vital.

\section{Developmental perspective in sport science}

\section{What types of changes and developments are currently required?}

Sports science includes a plethora of different academic fields. Thus, there is a high probability of producing error if the focus is only placed on theory itself or on the research laboratories. Actual training facilities and verification of its application in sports should be prioritized. Furthermore, active research in both laboratories and training sites along with the incorporation of modern technology, diverse information, and communication with related science fields will be required [5]. In the future, sport science will require harmony by including more academic fields. Hence, a more systematic approach and application should be attempted. Above all, sport science is a human science and functional characteristics related to the human body should be prioritized. To avoid distortion of the essence of sport, a limit should be placed on the research area. Most national sports players have stated that their biggest rivals while competing were themselves. In sports, all sorts of difficulties should be overcome to maximize physical abilities and exercise performance.

The main research direction of sport science is to improve sports performance in athletes and to improve health in nonathletes based on the manifestation mechanism of human capability. To maximize the sport performance of athletes, training is necessary, but optimal conditioning of the body is also required. Several scientific markers are used for exercise training processes and to maintain optimal conditioning. The markers include evaluation and prediction of the maximum sport ability, evaluation and analysis of training, physiological changes in different phases of training, maintenance of optimal conditioning, fatigue analysis, nutritional status analysis, and the use of biochemical or ergogenic aid. Molecular biological analysis is also widely used to evaluate and analyze health improvement exercise programs [6]. Genetic analysis using gene polymorphism, haplotype, and micro-array are important areas of sport science for the analysis of inherent factors for outstanding sports performance. Various genes associated with physical abilities, including the hereditary indicators of muscle strength ACTN-3, ACE, IGF-1 and myostatin, are being investigated to determine variance in their levels in different races or ethnic groups [7]. Development of training methods based on these differences is an important topic in sport science [8]. Along with biology, genetics is an important topic that arose in the new era's 4th industrial revolution. (See Table 1).

Diverse experimental results in sports science are being widely used in training fields [15]. However, there are still many challenges and a sense of distance. Sports science should be able to answer the athletes' and the coaches' questions. The difference between laboratories and training facilities should 
Table 1. Top 20 worldwide fitness trends for 2014-2019 [9-14]

\begin{tabular}{|c|c|c|c|c|c|c|}
\hline Rank & 2014 & 2015 & 2016 & 2017 & 2018 & 2019 \\
\hline 1 & HIIT & Body weight training & $\begin{array}{l}\text { Wearable } \\
\text { technology }\end{array}$ & Wearable technology & HIIT & Wearable technology \\
\hline 2 & Body weight training & HIIT & $\begin{array}{l}\text { Body weight } \\
\text { training }\end{array}$ & Body weight training & Group training & Group training \\
\hline 3 & $\begin{array}{l}\text { Educated, certified, \& } \\
\text { Experienced Fitness } \\
\text { Professionals }\end{array}$ & $\begin{array}{l}\text { Educated, certified, \& } \\
\text { Experienced Fitness } \\
\text { Professionals }\end{array}$ & HIIT & HIIT & $\begin{array}{l}\text { Wearable } \\
\text { technology }\end{array}$ & HIIT \\
\hline 4 & Strength training & Strength training & Strength training & $\begin{array}{l}\text { Educated, certified, \& } \\
\text { Experienced Fitness } \\
\text { Professionals }\end{array}$ & $\begin{array}{l}\text { Body weight } \\
\text { training }\end{array}$ & $\begin{array}{l}\text { Fitness programs for } \\
\text { older adults }\end{array}$ \\
\hline 5 & Exercise \& Weight loss & Personal training & $\begin{array}{l}\text { Educated, } \\
\text { certified, \& } \\
\text { Experienced Fitness } \\
\text { Professionals }\end{array}$ & Strength training & Strength training & Bodyweight training \\
\hline 6 & Personal training & Exercise \& Weight loss & Personal training & Group training & $\begin{array}{l}\text { Educated, certified, } \\
\text { \& Experienced } \\
\text { Fitness } \\
\text { Professionals }\end{array}$ & $\begin{array}{l}\text { Employing certified } \\
\text { fitness professionals }\end{array}$ \\
\hline 7 & $\begin{array}{l}\text { Fitness programs for } \\
\text { older adults }\end{array}$ & Yoga & Functional fitness & Exercise is medicine & Yoga & Yoga \\
\hline 8 & Functional fitness & $\begin{array}{l}\text { Fitness programs for } \\
\text { older adults }\end{array}$ & $\begin{array}{l}\text { Fitness programs } \\
\text { for older adults }\end{array}$ & Yoga & Personal training & Personal training \\
\hline 9 & $\begin{array}{l}\text { Group personal } \\
\text { training }\end{array}$ & Functional fitness & $\begin{array}{l}\text { Exercise \& Weight } \\
\text { loss }\end{array}$ & Personal training & $\begin{array}{l}\text { Fitness programs } \\
\text { for older adults }\end{array}$ & $\begin{array}{l}\text { Functional fitness } \\
\text { training }\end{array}$ \\
\hline 10 & Yoga & Group personal training & Yoga & Exercise \& Weight loss & Functional fitness & Exercise is medicine \\
\hline 11 & $\begin{array}{l}\text { Children and exercise } \\
\text { for the treatment/ } \\
\text { prevention of obesity }\end{array}$ & $\begin{array}{l}\text { Worksite health } \\
\text { promotion }\end{array}$ & $\begin{array}{l}\text { Group personal } \\
\text { training }\end{array}$ & $\begin{array}{l}\text { Fitness programs for } \\
\text { older adults }\end{array}$ & $\begin{array}{l}\text { Exercise \& Weight } \\
\text { loss }\end{array}$ & $\begin{array}{l}\text { Health/wellness } \\
\text { coaching }\end{array}$ \\
\hline 12 & $\begin{array}{l}\text { Worksite health } \\
\text { promotion }\end{array}$ & Outdoor activities & $\begin{array}{l}\text { Worksite health } \\
\text { promotion }\end{array}$ & Functional fitness & $\begin{array}{l}\text { Exercise is } \\
\text { medicine }\end{array}$ & Exercise for weight loss \\
\hline 13 & Core training & Wellness coaching & Wellness coaching & Outdoor activities & $\begin{array}{l}\text { Group personal } \\
\text { training }\end{array}$ & Mobile exercise apps \\
\hline 14 & Outdoor activities & Circuit training & Outdoor activities & $\begin{array}{l}\text { Group personal } \\
\text { training }\end{array}$ & Outdoor activities & $\begin{array}{l}\text { Mobility/myofascial } \\
\text { devices }\end{array}$ \\
\hline 15 & Circuit training & Core training & $\begin{array}{l}\text { Sport-specific } \\
\text { training }\end{array}$ & Wellness coaching & $\begin{array}{l}\text { Flexibility \& } \\
\text { mobility rollers }\end{array}$ & $\begin{array}{l}\text { Worksite health } \\
\text { promotion and } \\
\text { worldplace wellbeing } \\
\text { programs }\end{array}$ \\
\hline 16 & $\begin{array}{l}\text { Outcome } \\
\text { measurements }\end{array}$ & Sport-specific training & Flexibility & $\begin{array}{l}\text { Worksite health } \\
\text { promotion }\end{array}$ & $\begin{array}{l}\text { Licensure } \\
\text { for fitness } \\
\text { professionals }\end{array}$ & $\begin{array}{l}\text { Outcome } \\
\text { measurements }\end{array}$ \\
\hline 17 & Wellness coaching & $\begin{array}{l}\text { Children and exercise } \\
\text { for the treatment/ } \\
\text { prevention of obesity }\end{array}$ & $\begin{array}{l}\text { Smart phone } \\
\text { exercise apps }\end{array}$ & $\begin{array}{l}\text { Smart phone exercise } \\
\text { apps }\end{array}$ & Circuit training & Outdoor acitivities \\
\hline 18 & Sport-specific training & $\begin{array}{l}\text { Outcome } \\
\text { measurements }\end{array}$ & Circuit training & $\begin{array}{l}\text { Outcome } \\
\text { measurements }\end{array}$ & Wellness coaching & $\begin{array}{l}\text { Leisure for fitness } \\
\text { professionals }\end{array}$ \\
\hline 19 & $\begin{array}{l}\text { Work incentive } \\
\text { programs }\end{array}$ & $\begin{array}{l}\text { Work incentive } \\
\text { programs }\end{array}$ & Core training & Circuit training & Core training & $\begin{array}{l}\text { Small group personal } \\
\text { training }\end{array}$ \\
\hline 20 & Boot camp & Boot camp & $\begin{array}{l}\text { Outcome } \\
\text { measurements }\end{array}$ & $\begin{array}{l}\text { Flexibility \& mobility } \\
\text { rollers }\end{array}$ & $\begin{array}{l}\text { Sport-specific } \\
\text { training }\end{array}$ & $\begin{array}{l}\text { Postrehabilitation } \\
\text { classes }\end{array}$ \\
\hline
\end{tabular}


be minimized to bring the laboratory to the training field or to convert the training facility into a laboratory [16]. How? This is still an ongoing discussion.

Researchers have continuously put their efforts into performance enhancement and to develop effective training methods. In terms of continuous sustainability and quantitative factors, the importance of increased exercise was emphasized based on a dose-response relationship [17]. A search process to select an effective method, a repetition between exercise and rest for conducting more exercise volume, yielded interval training. Since people could perform high-intensity exercises, HIIT has been an important trend. HIIT [18], which was proposed as an effective body weight control method and cardiopulmonary training, is an exemplary training protocol with scientific basis for exercise training rooted in sport science.

\section{Sport science for health promotion}

Along with cancer, metabolic disease is the most representative cause of death. The effects of atherosclerosis and insulin sensitivity, the key factors of metabolic disease, on exercise training have been thoroughly reported in sport science research, and the results have surpassed the medical boundary. The sport science approach not only prevents diseases but also aids in the treatment of diseases. Many sport science approaches through immunohistochemistry, ELISA, cell culture, and expression of proteins/genes have been attempted for the development of evidence in cellular or molecular levels [19,20]. Recently, several studies have emphasized the importance of exercise intervention on aging-related changes such as negative changes on the body structure, decreased stamina and cognition, and Alzheimer's disease. Many health promotion studies have also attempted to biochemically analyze inflammation, the immune system, and oxidative stress. A study by López-Otín et al. [21] has defined the stages of aging from cellular and molecular biological perspectives as the following: (1) genomic instability, (2) telomere attrition, (3) epigenetic alterations, (4) loss of proteostasis, (5) deregulated nutrient sensing, (6) mitochondrial dysfunction, (7) cellular senescence, (8) stem cell exhaustion, and (9) altered intercellular communication. A study by Rebelo-Marques et al. [22] has reported that physical exercises to prevent aging are more important than what is known and should be further promoted.

What is required here that 'Evidence' must be presented. To further enhance and spread the diktat 'Exercise is Medicine', how can we find evidence that exercise and physical activity are effective in specific ranges of intensity based on different types? Although the limitations and disadvantages of sport science are assumed because of its intrinsic properties, its weakness is the lack of systematic and categorical evidences compared to actual medicine and pharmacology. Evidence that supports the effects of exercise training and physical activity on the human body in cellular or molecular levels are desperately needed [23]. For example, in relation to exercise effects, evidence must be clearly presented and must show improved muscle function, increased muscle mass, and activated secretion of myokine in specific perspectives such as visible, cellular, and molecular level evidences through muscle contraction [24]. Categorical evidence of the relationship between muscle contraction and exercise would emphasize the importance of sport science for effective and accurate exercise treatment. Similar cases can be observed in evidence-based academics, such as medicine. In the past, medicine has focused on diagnosis through clinical decision making. The evidence-based mechanism has led medicine to adopt evidence-based guidelines, systematic review, and qualitative evaluation of medical technology. Effort has been made to make evidence-based theory more applicable and extensive [25]. The process of development of evidencebased sports science includes questions on the applicability on the actual setting and collecting evidences of its answer. Along with verification and evaluation of the applicability of the answers, it would be necessary to incorporate field training experience. Sport science requires the use of the actual setting more than any other fields. Therefore, evidence-based data and actual setting experience should be incorporated more effectively.

The nutritional approach for enhancing human body functions includes a sufficient consumption of energy, increased energy storage as glycogen loading [26,27], supplementation of nutrients [28,29], development of functional drinks, and use of ergogenic aids. To overcome 


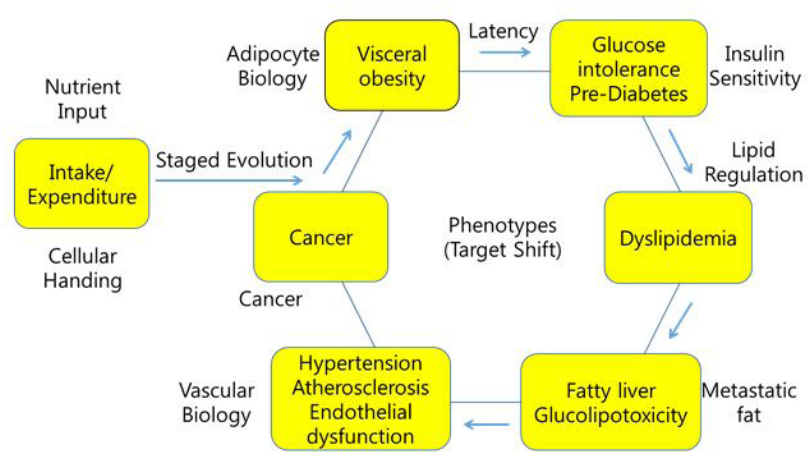

Figure 5. Phenotypic shifts metabolic syndrome [23]

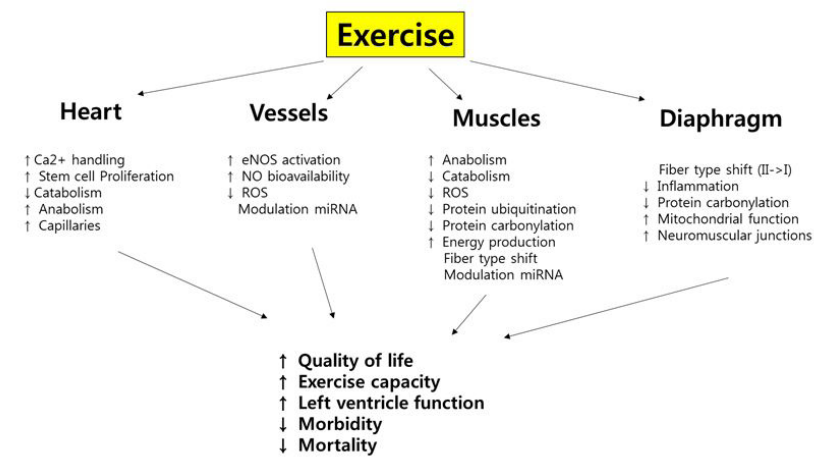

Figure 6. Summary of molecular effects that exercise training elicits on the heart, endothelium, skeletal muscle, and diaphragm finally leading to improvement spanning from quality of life to exercise capacity and morbidity and mortality [24].

limiting environmental factors, temperature, humidity, altitude, air pollution, and time, differences have been scientifically analyzed. The paradox theory, which requires delicate consideration, is very interesting. Therefore, the post-exercise training adaptation can block the opportunity to send the warning signal of general adaptation syndrome due to ergogenic aid and modern environmental control. Advancements of sport science can inhibit the effects of exercise training and can lead to disabled activation of body functions [30-32]. These results show the double-standard that may be noted when heavily depending on sport science. This implies that a more detailed and categorized level of scientific approach is required to enhance human body functions.

\section{Changes in the era and sport science}

Sport science involves many stages. These stages have focused on varying properties such as enhanced performance, public health promotion, human welfare, and economic activity. Throughout these stages, sport science has allowed for elite sport-based changes and researchers continuously strive to overcome difficult situations. Political misuse of sports, doping, sport alterations, and loss of humanity are problems created by excessive sport science, which have devaluated sports themselves. An elite-based philosophy led to a level of sport science that was obsessed with victory, which triggered severe chemical use, full-body swimsuits, and development of high-tech equipment. This flow could cause either a golden era or dark stage of sports and could produce severe worries and concerns. However, these stages might be natural obstacles that must be overcome for sport science to coexist with the human environment.

Increases in life expectancy and population of humans are important properties of changes in this era and are crucial factors that could bring future-oriented changes in sport science. On July 1, 2018, the Daily Mail, a publication from Great Britain, estimated that there were currently 962 million people above the age of 60 years $(12.3 \%$ of the entire population) and that number would be expected to increase to 2.1 billion in 2050 (22\% of the entire population) and 3.1 billion in 2100 by citing the report from Reuters [33]. Along with an increased elderly population and sports-active population, the sport injury rate has increased markedly. Hence, the importance of scientific rehabilitation training has been emphasized and the role of sport science in rehabilitation medicine has become more prominent. Sport injuries are a major limiting factor in athlete performance and sports injury prevention and rehabilitation are vital to improve quality of life. Since bodily functions decline after the 20 s even without injuries, effective rehabilitation is a mandatory program and sport science-based rehabilitation programs are necessary. Futuristically, everyone might require a sport science-based rehabilitation program.

\section{Advancement and convergence of sport science}

Sport science must be recognized as an important academic field that provides clear answers to the questions 
posed by the public, athletes, and coaches. Convergence with diverse modern sciences and evolution is suggested. Convergence of culture industry and increased participation in sports have brought positive effects, including healthy lifestyles, ICT innovation, IT software utilization, sociability among the elderly, development of global sport networks, strengthened tourism industry, and development of sensory virtual reality. Recently, sport have compounded with culture, engineering, technology, service, and media to further expand into different spectrums such as the 6Ts (BT (Bio), IT (information), NT (nano), ST (aerospace), ET (environment) and CT (culture)). Convergence of sports with industrial technology and marketing knowhow is important to yield high added value to the sport industry with global competitiveness. The accumulation of technology and knowhow during this process could also derive an additional unknown field of industry.

Along with the 4 th industrial revolution, a sport science would actively utilize big data [34] and artificial intelligence has already been predicted. Although conflicts with those who claim the importance of human-based development is predicted, convergence with virtual reality and robot sports is expected for further development of sports science. Along with big data use, collaboration with machine learning and deep learning would further increase the range of sport science. A new sports science may be developed to improve health promotion and performance. The main role of big data utilization is to predict the future through correlation. As stated by the Canadian hockey legend Wayne Gretzky, the trajectory of the puck, known only by the great athletes, will be predicted. In this future-changing process, the answer for 'why?', which indicates causality, should be analyzed. The value of future-oriented big data could indicate this 'why'.

Bionics, a fusion of bioengineering and electronic engineering, was the base for Cybathlon. Cybathlon is a good example that shows the future of sport science, especially regarding its segregated and vulnerable hierarchy. Sport science has yielded new knowledge and value through collaborations with related academics, such as ICT. Further development of sport science through active convergence with other academic fields is necessary. The major accomplishments of 'Sport Science Convergence Study Business' that took place recently in Korea included the wind tunnel/field test system that determined ski jump athletes' optimal chute/take-off/ glide poses (different variables such as angle between skis and angle between leg and ski were continuously altered until the optimal glide pose was determined), 'jump ski' that reflects each athlete's physical properties and preferences, decreased friction, 'ski wax', environmental control chamber that could accurately control different sport environment (highaltitude, low oxygen, temperature, humidity etc. that could be simulated) and super low weight 'flying disk' with internet of things platform.

\section{Conclusions}

Relative to other academic fields, sport science requires more reality and productivity. Active attempts to investigate in both laboratories and fields, analysis of actual settings, and experience-based interpretation are crucial to truly improve performance and further develop sport science. Sport science in the future will require association and harmony with more diverse academic fields, as well as utilization of modern technology and communication among diversified information technologies. An active association between sport science and sport culture is emphasized. The close relationship between sport and tourism could improve the value of sport brands and would further stimulate the economy. Considering the role of sport science and the prevalent social trends, sport science is not confined to academics but will expand further into economic, social, and cultural fields. To fuse with different academic fields and social trends, convergence with interdisciplinary sport science would be necessary. During this process, systematic and future-oriented activation for health promotion, improved performance, and incorporation of modern technology and industry are necessary to develop an effective cluster system. As a result, elite sports, the sport health industry, ICT convergence science, and sports culture will undergo compound promotion.

In terms of health promotion and enhanced performance, there is more field usability and development in the field of sport science than other fields. Regarding the academic 
perspective, repetitive cycles of systematical convergence have brought accumulation of new theories and knowledge. The new role of sport science in health promotion and performance enhancement helps to develop an evidencebased exercise training program and system with a helping hand from big data and artificial intelligence. New sports that jump between the boundaries of real and virtual worlds are expected to be developed.

Recovery of humanity is an important consideration in the modernization of sport science. Changes in human body structure have coexisted among cultures and continuous effort has been put into recovering human-based development of sport. Although the human body has undergone transformations to attain visually attractive and beautiful forms, a concern is raised for further distortion. Sport science, which began with the goal of health promotion and enhanced performance, should collaborate with more academic fields and should protect the human body from distortion. There have been many changes in human science based on cultures and religions around the world. Hence, effort to develop sport science based on human requirements should be made concomitantly.

\section{Acknowledgments}

This research was modified from presented paper of $56^{\text {th }}$ KAHPERD Conference and $30^{\text {th }}$ International Sport Science Congress in 2018

\section{Conflicts of Interest}

The author declare no conflicts of interest

\section{References}

1. Jin $\mathrm{H}, \mathrm{Na}$ Y-I. It is time to investigate the history of sport science. Kor J Phys Educat. 2017; 56(1):11-23.

2. Lobelo F, Stoutenberg M, Hutber A. The exercise is medicine global health initiative: a 2014 update. Brit J Sports Med. 2014; 48(22):1627-1633.

3. Kim K. Perspective and role of sport science. J Physical Education, 2014; 10(1):1-10.
4. de Koning JJ, Houdijk H, de Groot G, Bobbert MF. From biomechanical theory to application in top sports: the Klapskate story. J Biomech. 2000; 33:12251229. PubMed ID: 10899331 doi:10.1016/S00219290(00)00063-4

5. Foster C. In quest of the unified field theory of exercise training. Int J Sports Physiol Perf. 2015; 10:1-2. doi:10.1123/ijspp.2014-0542

6. Kim K. Effective training strategy for the improvement of exercise performance. J Coaching Development, 2013; 15(1):72-83.

7. Wang G, Padmanabhan S, Wolfarth B, et al. Genomics of elite sporting performance: what little we know and necessary advances. Advances in Genetics, 2013; 84:123-149.

8. Kim K. Genetic factors and exercise performance. J Coaching Development, 2004; 6(2):45-53.

9. Thompson WR. Worldwide survey of fitness trends for 2014. ACSM's Health \& Fitness Journal, 2013; 17(6):10-20.

10. Thompson WR. Worldwide survey of fitness trends for 2015: what's driving the market. ACSM's Health \& Fitness Journal, 2014; 18(6):8-17.

11. Thompson WR. Worldwide survey of fitness trends for 2016: $10^{\text {th }}$ anniversary edition. ACSM's Health \& Fitness Journal, 2015; 19(6):9-18.

12. Thompson WR. Worldwide survey of fitness trends for 2017. ACSM's Health \& Fitness Journal, 2016; 20(6):817.

13. Thompson WR. Worldwide survey of fitness trends for 2018: The CREP Edition. ACSM's Health \& Fitness Journal, 2017; 21(6):10-19.

14. Thompson WR. Worldwide survey of fitness trends for 2019. ACSM’s Health \& Fitness Journal, 2018; 22(6):1017.

15. Foster C. Sports science: progress, hubris, and humility. International Journal of Sports Physiology and Performance, (Ahead of Print), 2019: https://doi. org/10.1123/ijspp.2018-0982

16. Kim K. Sport physiology in lab and field. J Sport Science, 2010; 1(1):1-6.

17. Crump KS, Hoel DG, Langley CH, Peto R. Fundamental 
carcinogenic processes and their implications for low dose risk assessment. Cancer Research. 1976; 36 (9 Part1):2973-2979.

18. De Lorenzo A, Van Bavel D, de Moraes, R, Tibiriça EV. High-intensity interval training or continuous training, combined or not with fasting, in obese or overweight women with cardiometabolic risk factors: study protocol for a randomised clinical trial. BMJ Open. 2018; 8(4):e019304.

19. Brown AE, Walker M. Genetics of Insulin Resistance and the Metabolic Syndrome. Curr Cardiol Rep. 2016; 18:75. doi: 10.1007/s11886-016-0755-4.

20. Magge SN, Goodman E, Armstrong SC. Committee on Nutrition Section on Endocrinology, Section on Obesity. The metabolic syndrome in children and adolescents: shifting the focus to cardiometabolic risk factor clustering. Pediatrics, 2017; 140(2):e20171603.

21. López-Otín C, Blasco MA, Partridge L, Serrano M, Kroemer G. The hall-marks of aging. Cell, 2013; 153(6):1194-1217.

22. Rebelo-Marques A, Lages A, Andrade R, Ribeiro CF, Mota-Pinto A, Carrilho F, Espregueira-Mendes J. Aging hallmarks: the benefits of physical exercise. Front. Endocrinology (Lausanne), 2018; 9:258, doi: 10.3389/ fendo.2018.00258.

23. Winzer EB, Woitek F, Linke A. Physical activity in the prevention and treatment of coronary artery disease. J Am Heart Assoc. 2018; 7(4):e007725.

24. Adams V, Reich B, Uhlemann M, Niebauer J. Molecular effects of exercise training in patients with cardiovascular disease: focus on skeletal muscle, endothelium, and myocardium. Am J Physiol Heart Circ Physiol. 2017; 313:H72-H88.

25. Kim S. Evidence based medicine. J Kor Soc Health-Syst Pharm. 2008; 25(4):261-269.
26. Hermansen L, Hultman E, Saltin B. Muscle glycogen during prolonged severe exercise. Acta Physiol Scand. 1967; 71:129-139.

27. Bergstrom J, Hermansen L, Hultman E. Diet, muscle glycogen and performance. Acta Physiol Scand. 1967; 71:140-150.

28. Karlsson J, Saltin B. Diet, muscle glycogen and endurance performance. J Appl Physiol. 1971; 31:203-206. PubMed ID: 5558241 doi:10.1152/jappl.1971.31.2.203

29. Sherman WM, Costill DL, Fink WJ, Miller JM. Effect of exercise-diet manipulation on muscle glycogen and its subsequent utilization during performance. Int J Sports Med. 1981; 2:114-118. PubMed ID: 7333741 doi:10.1055/s-2008-1034594.

30. Paulsen G, Hamarsland H, Cumming KT, Johansen RE, Hulmi JJ, Børsheim E, Wiig H, Garthe I, Raastad T. Vitamin C and E supplementation hampers cellular adaptation to endurance training in humans: a doubleblind, randomised, controlled trial. J Physiology, 2014; 592(8):1887-1901.

31. Gomez-Cabrera M, Ristow M, Viña J. Antioxidant supplements in exercise: worse than useless? Am J Physiol Endocrinol Metab. 2012; 302(4):476-477.

32. McLeay Y, Stannard S, Houltham S, Starck C. Dietary thiols in exercise: oxidative stress defence, exercise performance, and adaptation. J Int Soc Sports Nutrition, 2017; 14:12, https://doi.org/10.1186/s12970-017-0168-9 33. United Nations, Department of Economic and Social Affairs, Population Division. World Population Prospects: The 2017 Revision, Key Findings and Advance Tables. 2017; Working Paper No. ESA/P/ $\mathrm{WP} / 248$.

34. Cho JH. Utilization and prospect of sport big data. The Korean Journal of Measurement and Evaluation in Physical Education and Sports Science, 2012; 14(3):111. 